\title{
QUALITY BY DESIGN APPROACH TO STABILITY-INDICATING REVERSE-PHASE HIGH-PERFORMANCE LIQUID CHROMATOGRAPHY METHOD DEVELOPMENT, OPTIMIZATION, AND VALIDATION FOR THE ESTIMATION OF SIMEPREVIR IN BULK DRUG
}

\author{
VANITHA C ${ }^{1,2}$, SATYANARAYANA SV ${ }^{3}$, BHASKAR REDDY $\mathrm{K}^{4 *}$ \\ ${ }^{1}$ Department of Pharmaceutical Sciences, Jawaharlal Nehru Technological University, Ananthapuramu, Andhra Pradesh, India. \\ ${ }^{2}$ Department Pharmaceutical Sciences, Sri Venkateswara College of Pharmacy, Chittoor, Andhra Pradesh, India. ${ }^{3}$ Department of \\ Chemical Engineering, Jawaharlal Nehru Technological University Anantapur, Ananthapuramu, Andhra Pradesh, India. ${ }^{4}$ Department of \\ Pharmaceutics, Sri Venkateswara College of Pharmacy, Chittoor, Andhra Pradesh, India. Email: bhaskurra@gmail.com
}

Received: 13 January 2019, Revised and Accepted: 19 March 2019

Objective: A simple, robust, precise, and selective stability-indicating liquid chromatography (LC) method (reverse-phase high-performance LC) was developed for the estimation of simeprevir through quality by design paradigm.

Methods: The chromatographic separation was performed on Water's 2695(Alliance) equipped with a photodiode array detector at $300 \mathrm{~nm}$. The method was developed on Discovery C18 column $(250 \times 4.6,5 \mathrm{~mm})$ using orthophosphoric acid and acetonitrile $(55: 45 \% \mathrm{v} / \mathrm{v})$ with the flow rate of $1 \mathrm{ml} / \mathrm{min}$ at $30^{\circ} \mathrm{C}$. The degradation studies of simeprevir were carried out under the stress conditions of hydrolysis (acid, base, and neutral), oxidation, photolytic, and thermal as per the International Conference on Harmonization (ICH) guidelines. The peroxide hydrolysis shows more critical impurities which were well resolved from pure drug with the application of design of experiment and optimized the method.

Results: Independent variables (critical analytical attributes) selected for the method optimization were mobile phase ratio, flow rate, and temperature of the column based on the risk assessment. The retention time and resolution were selected as the method response. In response surface method, the central composite design and $2^{3}$ factorial designs were employed for the optimization of the method. The polynomial equation was derived for the estimation of method response.

Conclusion: The method was optimized for better resolution among the drug, and impurity peaks were then validated as per the ICH parameters.

Keywords: Central composite design, Design of experiments, Method variables, Quality by design and stability-indicating assay.

(c) 2019 The Authors. Published by Innovare Academic Sciences Pvt Ltd. This is an open access article under the CC BY license (http://creativecommons. org/licenses/by/4. 0/) DOI: http://dx.doi.org/10.22159/ajpcr.2019.v12i5.32027

\section{INTRODUCTION}

One of the most crucial steps in the development of pharmaceutical products is to assess the stability of the product. The stabilityindicating assay can assess the stability of the product by subjecting the product under stress condition. It is essential to separate, detect, and quantify the pharmaceutical and its degradation products without interference by stability-indicating assay method. The convenient method to achieve the goal of stability-indicating method is reversephase (RP) liquid chromatography (LC), but often this method encounters the method failure or method transferability problem. This problem arises due to the lack of understanding of product and process. The success of a LC stability-indicating assay totally depends on its selectivity of the method [1]. To establish a robust, selective stability-indicating method, it requires deeper knowledge on the product and process along with the identification of risk factors. Hence, the quality by design (QbD) paradigm's principles have been utilized to develop a successful stability-indicating method. The International Conference on Harmonization (ICH) Q8 (R1) guideline defines $\mathrm{QbD}$ as "a systematic approach to development that begins with predefined objectives and emphasizes product and process understanding and process control, based on sound science and quality risk management" $[2,12,13]$.

Hepatitis $\mathrm{C}$ is a liver disease caused by the hepatitis C virus (HCV); the virus can cause both acute and chronic hepatitis. In recent years, progress in the development of direct-acting antiviral to treat chronic
$\mathrm{HCV}$ infection has accelerated enormously, so the number of affected people count was decreased in worldwide. According to the WHO's Global Hepatitis, report estimates that 71 million people in 2015 were living with $\mathrm{HCV}$, down from an earlier estimate of 130 million to 150 million [3]. Simeprevir is the second-generation NS3/4A protease inhibitors which was used in the treatment of genotype $1 \mathrm{HCV}$ infection (Fig. 1). NS3/4A protease acts on NS3 site for cleaving and generation of new proteins. Simeprevir is competitive, macrocyclic NS3/4A protease inhibitor that inhibits HCV NS3/4A protease's cleavage of the HCV polyprotein by binding non- covalently and preventing viral replication in infected cells $[4,5]$.

In the literature review, there was one method reported on stabilityindicating assay of simeprevir [6] and few bioanalytical methods were developed using LC with tandem mass spectrometry (MS) [7], ultra-performance liquid chromatography-MS [8], and isocratic RP high-performance LC (RP-HPLC) [9]. There was a spectrophotometric method for the estimation of Simeprevir and its oxidative degradation product [10] and one molecular modeling, in-silico toxicity by spectrofluorimetry method on simeprevir [11].

It is a clear evident from the literature, and no method has been developed through $\mathrm{QbD}$ approach. The reported stability-indicating method also not focused on any risk assessment and robustness of the method. Hence, there is a need to develop a robust, precise, simple, cost-effective, and selective stability-indicating RP-HPLC method on simeprevir in bulk drug through the QbD approach. 


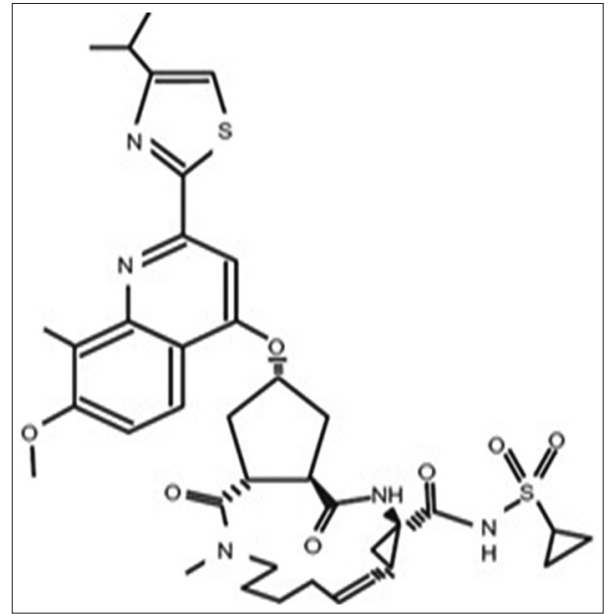

Fig. 1: Structure of simeprevir

\section{MATERIALS AND METHODS}

\section{Reagents and chemicals}

The active pharmaceutical ingredient was purchased from MSN Pharmaceuticals, Hyderabad. HPLC-grade water was purchased from Rankem, Avantor Performance Materials India Limited. Orthophosphoric acid (OPA) was purchased from RFCL, Rankem Limited, India. High-purity water was prepared using a Millipore Milli Q Plus purification system.

\section{Instrument}

LC equipment used for the development was WATERS 2695 equipped with a photodiode array (PDA) detector using Empower 2 software (Waters Corporation, Milford, MA, USA).

\section{Chromatographic conditions}

The chromatographic separation was performed on Discovery $\mathrm{C}_{18}(250 \mathrm{~mm} \times 4.6,5 \mu \mathrm{m})$ at $300 \mathrm{~nm}$. The column temperature was maintained at $30^{\circ} \mathrm{C}$. The mobile phase was OPA and acetonitrile (ACN) (55:45) with a flow rate of $1 \mathrm{ml} / \mathrm{min}$.

\section{Preparation of standard solutions}

\section{Buffer (0.1\% OPA)}

Add $1 \mathrm{ml}$ of OPA solution in a $1000 \mathrm{ml}$ of volumetric flask, add about $100 \mathrm{ml}$ of milli-Q water and final volume make up to $1000 \mathrm{ml}$ with milli-Q water.

\section{Standard preparation}

Accurately weighed and transferred $25 \mathrm{mg}$ of simeprevir working standards into a $25 \mathrm{ml}$ clean dry volumetric flask, add three-fourth volume of diluents, sonicated for $5 \mathrm{~min}$, and make up to the final volume with diluents.

\section{Standard preparation for linearity}

Pipette $0.25,0.50,0.75,1.0,1.25$, and $1.50 \mathrm{ml}$ of above standard stock solution into $10 \mathrm{ml}$ of standard flask and make up to the mark with diluents. The concentration of simeprevir in the prepared solution was $25,50,75,100,125$, and $150 \mu \mathrm{g} / \mathrm{ml}$.

\section{Standard preparation for degradation}

About $1 \mathrm{ml}$ of stock solution of simeprevir was taken separately and treated with acid, base, hydrogen peroxide separately at different Concentrations. After degradation the solution was neutralised and diluted to obtain $100 \mathrm{ppm}$ of simeprevir. Later it was injected into LC system.

\section{Design of expert software}

The design expert software 11.0.5.0 free trial version was used to plan the experiment's design.

\section{RESULTS AND DISCUSSION}

\section{Defining quality target profile}

It is a prospective summary of quality characteristics of a drug product taking into account together with the attributes affecting method performance. The major quality characteristic of a drug product which affects the method performances includes dosage form, color, and impurity percentage.

\section{Selection of chromatographic conditions}

Simeprevir maximum absorbance wavelength was selected at $300 \mathrm{~nm}$ from scanning the range of $200-400 \mathrm{~nm}$ using $25 \mu \mathrm{g} / \mathrm{ml}$ of standard solution of the drug. The elution was carried on C8 and C18 column, but the peak shape obtained on Discovery C18 column with good system suitability parameters. The PDA detector was used to detect the simeprevir. The mobile phase used for the detection was OPA and ACN in the ratio of 55:45 at the flow rate of $1 \mathrm{ml} / \mathrm{min}$. The column temperature was maintained at $30^{\circ} \mathrm{C}$.

\section{Forced degradation}

Stress degradation studies of simeprevir were carried out under hydrolysis (acid, base, and neutral), oxidation, and photolytic. The drug was treated with $0.1 \mathrm{~N} \mathrm{HCl}$ for $6 \mathrm{~h}$ at $60^{\circ} \mathrm{C}$ to perform acid degradation, $1 \mathrm{~N} \mathrm{NaOH}$ for $3 \mathrm{~h}$ at $60^{\circ} \mathrm{C}$ for base degradation, and $20 \% \mathrm{H}_{2} \mathrm{O}_{2}$ for $3 \mathrm{~h}$ at $60^{\circ} \mathrm{C}$ for peroxide degradation. The standard drug solution was placed in an oven at $105^{\circ} \mathrm{C}$ for $6 \mathrm{~h}$ to study dry heat degradation. Stress testing under neutral conditions was studied by refluxing the drug in water for $72 \mathrm{~h}$ at a temperature of $60^{\circ} \mathrm{C}$. The chromatograms of forced degradation studies of simeprevir are shown in Fig. 2.

The simeprevir drug was stable under the stress condition of thermal, UV, and water. The drug was treated under acidic and basic condition, and its shows degradation with one degradant peak in each condition. However, in 20\% hydrogen peroxide, the peroxide shows two degradant peaks which are more likely to coelute with the drug peak. Results of the percentage of degradations of simeprevir lies within accepted limits and are mentioned in Table 1.

Hence, it is evident that the peroxide condition has a significant effect on the stability of simeprevir drug than any other stress condition. Hence, the emphasis has given the peroxide stress condition to understand method variables on method response. So, design of experiments (DoE) has applied on peroxide stress condition.

\section{Risk assessment}

The critical method variables are the parameters which have impact on the quality target profile. "It is a systematic process for the assessment, control, communication, and review of risks to the quality across the product lifecycle." It is done throughout the life cycle and typically performed. The risk factors for simeprevir method were identified based on the theoretical and practical knowledge and are given in Table 2.

\section{Design of experiment}

Based on the risk assessment, the critical analytical attributes were identified \% OPA in the mobile phase, the flow rate, and column temperature. The method responses selected were retention time of the drug and resolution between the drug peak and degradation peak 1 which likely coelutes and leads to method failure often. Preferably in response surface method, $2^{3}$ factorial designs were selected. The selected method responses and its levels are given in Table 3.

The central composite design was selected and 20 chromatogram runs were conducted as per DoE design, and the method responses of each run are mentioned in Table 4.

\section{Statistical analysis of method responses}

Analysis of variance (ANOVA) for method response 1 - retention time The ANOVA of regression parameters of the predicted response surface quadratic model for retention time was obtained from DoE software 


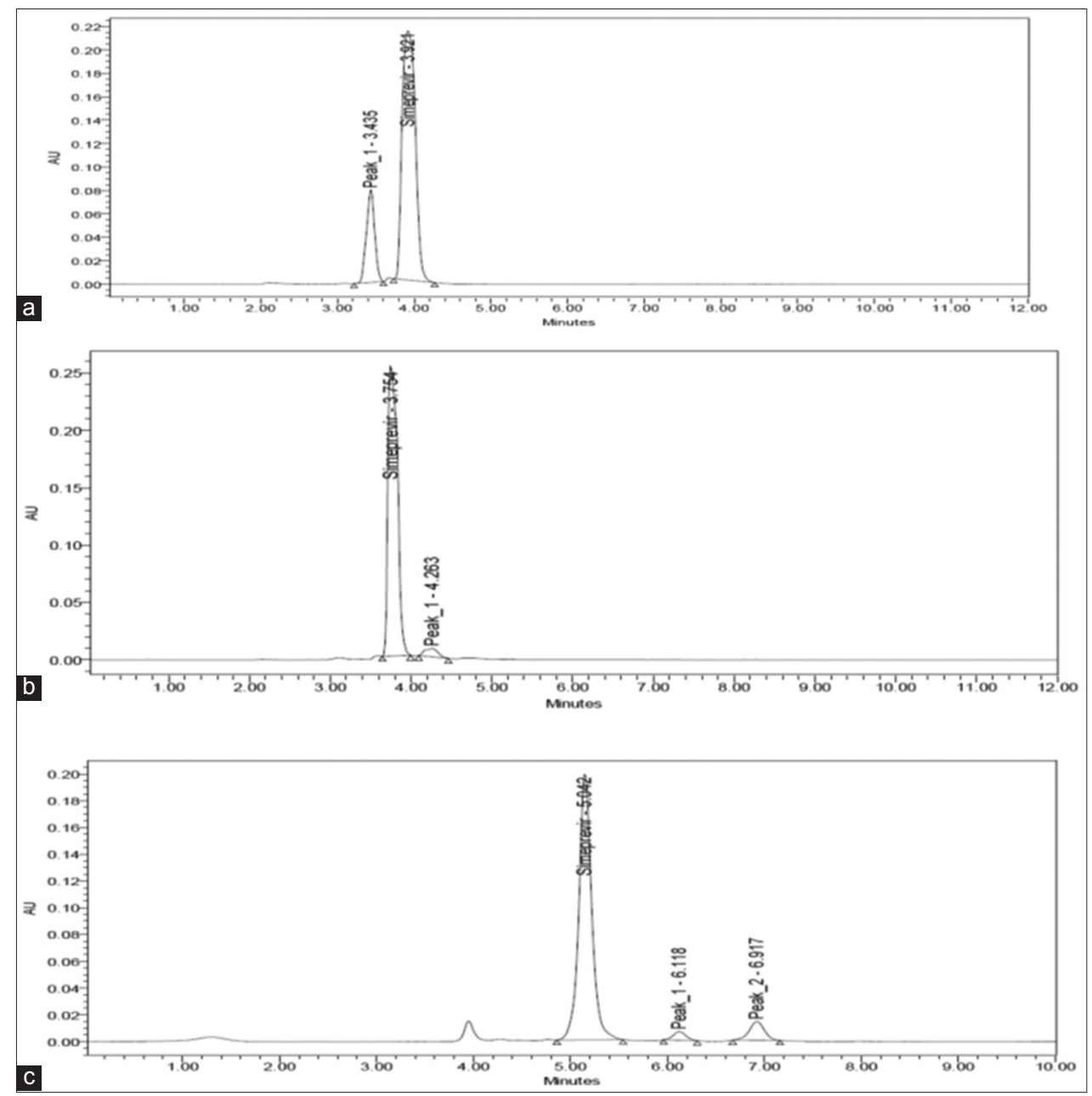

Fig. 2: Forced degradation chromatograms of simeprevir. (a) Acid degradation: In $0.1 \mathrm{~N} \mathrm{HCl}$ at $60^{\circ} \mathrm{C}$ for $6 \mathrm{~h}$, (b) Base degradation: In $1 \mathrm{~N}$ $\mathrm{NaOH}$ at $60^{\circ} \mathrm{C}$ for $3 \mathrm{~h}$, (c) Peroxide degradation: In $20 \%$ hydrogen peroxide at $60^{\circ} \mathrm{C}$ for $3 \mathrm{~h}$

Table 1: Degradation percentage of simeprevir under various stress conditions

\begin{tabular}{llll}
\hline Condition & $\begin{array}{l}\text { \% Assay } \\
\text { initial }\end{array}$ & $\begin{array}{l}\text { \% Assay after } \\
\text { degradation }\end{array}$ & \% Degradation \\
\hline Acid & 100.00 & 79.48 & 20.51 \\
Base & 100.00 & 70.29 & 29.70 \\
Peroxide & 100.00 & 78.82 & 21.17 \\
Thermal & 100.00 & 101.99 & 0.651 \\
UV degradation & 100.00 & 93.37 & 6.625 \\
\hline
\end{tabular}

Table 2: Critical method parameters

\begin{tabular}{ll}
\hline Condition & Criticality \\
\hline HPLC instrument & Control \\
Column & Control \\
Detector & Control \\
API standard & Control \\
Glasswares & Control \\
pH of mobile phase & Control \\
Percentage of OPA in mobile phase & Variable $\mathrm{X}_{1}$ \\
Flow rate of Mobile phase & Variable $\mathrm{X}_{2}$ \\
Temperature of column & Variable $\mathrm{X}_{3}$ \\
\hline
\end{tabular}

HPLC: High-performance liquid chromatography, OPA: Orthophosphoric acid

and is presented in Table 5. The model shows $\mathrm{F}$ value of 36.46 and low probability value which states that the model was significant for
Table 3: Design of experiments - Levels of variables

\begin{tabular}{lllll}
\hline Name of variables & Units & $\begin{array}{l}\text { Low } \\
\text { level-1 } \\
\text { level }\end{array}$ & $\begin{array}{l}\text { Mid } \\
\text { level } \\
\text { 0 level }\end{array}$ & $\begin{array}{l}\text { High } \\
\text { level+1 } \\
\text { level }\end{array}$ \\
\hline \% mobile phase (OPA) & $\%$ & 50.00 & 55.00 & 60.00 \\
Flow rate & $\mathrm{ml} / \mathrm{min}$ & 0.90 & 1.00 & 1.10 \\
Column temperature & ${ }^{\circ} \mathrm{C}$ & 28 & 30 & 32 \\
\hline
\end{tabular}

OPA: Orthophosphoric acid

retention time. Values of "Prob $>F$ " $<0.0500$ indicate that model terms were significant. In this case, $\mathrm{A}, \mathrm{B}$ and $\mathrm{A}^{2}$ were significant model terms. Values $>0.1000$ indicate that the model terms were not significant. The The " Lack of Fit F-Value of 4.88 implies that there was a $5.34 \%$ chance that it could occur due to noise. Adequate precision 22.230 indicates an adequate signal. This model can be utilized to navigate the design space.

Based on results, the response surface model constructed in this study for predicting retention time was considered reasonable. The final regression model, in terms of their coded factors was given below equation.

$\mathrm{RT}=+5.26+2.24 \mathrm{~A}-0.29 \mathrm{~B}-0.049 \mathrm{C}+0.072 \mathrm{~A} \times \mathrm{B}-5.375 \mathrm{e}^{-0.003} \mathrm{~A} \times \mathrm{C}-0.023 \mathrm{~B} \times$ $\mathrm{C}+0.74 \mathrm{~A}^{2}+0.091 \mathrm{~B}^{2}+0.053 \mathrm{C}^{2}$

The equation in terms of actual factors can be used to make predictions about the response of retention time and process variables by polynomial equation. 
Table 4: Central composite design for screening of method parameters

\begin{tabular}{|c|c|c|c|c|c|c|}
\hline \multirow[t]{2}{*}{ Std. } & \multirow[t]{2}{*}{ Run } & \multirow{2}{*}{$\begin{array}{l}\text { Factor } 1 \\
\text { A: Mobile phase } \\
\%\end{array}$} & \multirow{2}{*}{$\begin{array}{l}\text { Factor } 2 \\
\text { B: Flow rate } \\
\mathrm{ml} / \mathrm{min}\end{array}$} & \multirow{2}{*}{$\begin{array}{l}\text { Factor } 3 \\
\text { C: Temperature } \\
{ }^{\circ} \mathrm{C}\end{array}$} & \multirow{2}{*}{$\begin{array}{l}\text { Response } 1 \\
\text { Retention time }\end{array}$} & \multirow{2}{*}{$\begin{array}{l}\text { Response } 2 \\
\text { Resolution }\end{array}$} \\
\hline & & & & & & \\
\hline 13 & 2 & 55 & 1 & 26.63 & 5.165 & 3.9 \\
\hline 3 & 3 & 50 & 1.1 & 28 & 3.687 & 4.4 \\
\hline 1 & 4 & 50 & 0.9 & 28 & 4.516 & 2.5 \\
\hline 14 & 5 & 55 & 1 & 33.36 & 4.949 & 4.5 \\
\hline 19 & 6 & 55 & 1 & 30 & 5.105 & 3.9 \\
\hline 9 & 7 & 46.59 & 1 & 30 & 3.594 & 4 \\
\hline 11 & 8 & 55 & 0.83 & 30 & 5.499 & 4.2 \\
\hline 18 & 9 & 55 & 1 & 30 & 5.447 & 4 \\
\hline 8 & 10 & 60 & 1.1 & 32 & 8.47 & 1.6 \\
\hline 10 & 11 & 63.40 & 1 & 30 & 10.425 & 2 \\
\hline 12 & 12 & 55 & 1.16 & 30 & 4.831 & 3.9 \\
\hline 4 & 13 & 60 & 1.1 & 28 & 8.636 & 1.6 \\
\hline 20 & 14 & 55 & 1 & 30 & 5.044 & 3.5 \\
\hline 7 & 16 & 50 & 1.1 & 32 & 3.608 & 5.3 \\
\hline 15 & 17 & 55 & 1 & 30 & 5.042 & 4 \\
\hline 17 & 18 & 55 & 1 & 30 & 5.559 & 3.5 \\
\hline 16 & 19 & 55 & 1 & 30 & 5.679 & 4 \\
\hline 5 & 20 & 50 & 0.9 & 32 & 4.465 & 2.6 \\
\hline
\end{tabular}

Table 5: ANOVA for quadratic model for method response - retention time

\begin{tabular}{|c|c|c|c|c|c|c|}
\hline Source & $\begin{array}{l}\text { Sum of } \\
\text { squares }\end{array}$ & df & $\begin{array}{l}\text { Mean } \\
\text { square }\end{array}$ & F-value & p value & \\
\hline Model & 77.43 & 9 & 8.60 & 36.46 & $<0.0001$ & \multirow[t]{10}{*}{ Significant } \\
\hline A-MP & 68.26 & 1 & 68.26 & 289.23 & $<0.0001$ & \\
\hline B-FR & 1.12 & 1 & 1.12 & 4.76 & 0.0541 & \\
\hline C-TMP & 0.033 & 1 & 0.033 & 0.14 & 0.7183 & \\
\hline $\mathrm{AB}$ & 0.042 & 1 & 0.042 & 0.18 & 0.6824 & \\
\hline $\mathrm{AC}$ & $2.311 \mathrm{E}-004$ & 1 & $2.311 \mathrm{E}-004$ & $9.794 \mathrm{E}-004$ & 0.9757 & \\
\hline$A^{2}$ & 7.96 & 1 & 7.96 & 33.74 & 0.0002 & \\
\hline $\mathrm{B}^{2}$ & 0.12 & 1 & 0.12 & 0.51 & 0.4925 & \\
\hline $\mathrm{C}^{2}$ & 0.040 & 1 & 0.040 & 0.17 & 0.6876 & \\
\hline Residual & 2.36 & 10 & 0.24 & & & \\
\hline $\begin{array}{l}\text { Lack of } \\
\text { fit }\end{array}$ & 1.96 & 5 & 0.39 & 4.88 & 0.0534 & \multirow[t]{3}{*}{$\begin{array}{l}\text { Not } \\
\text { significant }\end{array}$} \\
\hline Pure & 0.40 & 5 & 0.080 & & & \\
\hline Error & & & & & & \\
\hline \multicolumn{7}{|c|}{ ANOVA summary } \\
\hline SD & 0.49 & PRESS & 15.39 & $\begin{array}{l}\text { Adequate } \\
\text { precision }\end{array}$ & 22.230 & \\
\hline $\mathrm{R}^{2}$ & 0.9704 & $\begin{array}{l}\text { Adjusted } \\
\mathrm{R}^{2}\end{array}$ & 0.9438 & Predicted $\mathrm{R}^{2}$ & 0.8072 & \\
\hline
\end{tabular}

$\mathrm{RT}=+98.83993-2.95197 \times \mathrm{MP}-25.55454 \times \mathrm{FR}-0.67258 \times \mathrm{TMP}+0.14475$ $\mathrm{MP} \times \mathrm{FR}-5.37500 \mathrm{E}^{-004} \mathrm{MP} \times \mathrm{TMP}-0.11688 \mathrm{FR}-\mathrm{TMP}+0.029732 \mathrm{MP}^{2}+$ $9.11590 \mathrm{FR}^{2}+0.013244 \mathrm{TMP}^{2}$

\section{D and contour graph for retention time}

The 3D surface response and contour plots of the quadratic model were given by the Design-Expert software which provides the interactive relationship of two factors on response by keeping constant of the third factor.

The contour and 3D surface response in Fig. 3 states that the highest retention time reached below 8 min only when maintaining the $60.00 \%$ of OPA in mobile phase and $1.10 \mathrm{ml} / \mathrm{min}$ flow rate by keeping constant of column temperature at $30^{\circ} \mathrm{C}$. Below $51 \%$ of OPA at $0.9 \mathrm{ml} / \mathrm{min}$, the retention time of the drug was eluted $<4$ min which is not recommended.
The flow rate kept constant and interaction of \% OPA and column temperature were studied on retention time as shown in Fig. 4. It shows that, at low levels of \% OPA and temperature, retention time reduced to below $4 \mathrm{~min}$. At high levels of variables, the retention time achieved at $7.6 \mathrm{~min}$.

The \% OPA in the mobile phase kept constant at 55 and interaction of flow rate on column temperature was studied. These two factors show the least effect on retention time of the drug. Changing these two factors from low to high levels which has least effect on retention time of Simeprevir. Hence, these two-term interactions were insignificant in this model.

ANOVA for method response 2 - resolution

The ANOVA of regression parameters of the predicted response surface quadratic model for resolution was obtained from DoE software and is 
given in Table 6. The Model F-value of 10.51 implies that the model was significant. There is only a $0.05 \%$ chance that a "Model F-value" this large could occur due to noise. Values of "Prob $>$ F" $<0.0500$ indicate that model terms were significant. In this case, $\mathrm{A}, \mathrm{AB}$, and $\mathrm{A}^{2}$ were significant model terms. Values $>0.1000$ indicate that the model terms were not significant. The "Lack of Fit F-Value of 4.67 implies that there was a $5.34 \%$ chance that it could occur due to noise. The "Predicted R-Squared" of 0.3739 was not as close to the "Adjusted R-squared" by 0.8183 as one might normally expect. However, the "adequate precision" ratio of 12.716 indicates an adequate signal, which measures the signal to noise ratio.

Based on results, the response surface model constructed in this study for predicting retention time was considered reasonable. The final regression model, in terms of their coded factors was given below equation.

\section{$\mathrm{R} 2=+3.84-0.58 \times \mathrm{A}+0.022 \times \mathrm{B}+0.15 \mathrm{C}-1.05 \mathrm{~A} \times \mathrm{B}-0.13 \mathrm{~A} \times \mathrm{C}+0.10 \mathrm{~B} \times \mathrm{C}$ $-0.42 \mathrm{~A}^{2}-0.049 \times \mathrm{B}^{2}+4.492 \mathrm{E}^{-003} \times \mathrm{C}^{2}$}

The equation in terms of actual factors can be used to make predictions about the response of retention time and process variables by polynomial equation.

\section{$\mathrm{R} 2=-167.93273+4.20537 \times \mathrm{MP}+110.42452 \times \mathrm{FR}+0.19367 \times \mathrm{TMP}-$ $2.10000 \mathrm{MP} \times \mathrm{TMP}+0.50000 \mathrm{FR} \times \mathrm{TMP}-0.016791 \mathrm{MP}^{2}-4.85409 \mathrm{FR}^{2}$ $+1.12304 \mathrm{E}^{-003} \mathrm{TMP}^{2}$}

\section{D and contour graph for retention time}

The column temperature was kept constant at $30^{\circ} \mathrm{C}$, and the remaining two variables such as \% OPA and flow rate interaction effect on resolution are studied from Fig. 5. At higher levels, the \% OPA and flow rate give low resolution $(<2)$. \% OPA ranges lies above $50.00 \%$ to below $57.50 \%$ at the flow rate of $1.0 \mathrm{ml} / \mathrm{min}$ or lower levels yield good resolution between the peaks.

The flow rate kept constant at $1 \mathrm{ml} / \mathrm{min}$, and then the interaction of \% OPA and column temperature on resolution was studied from Fig. 6. It

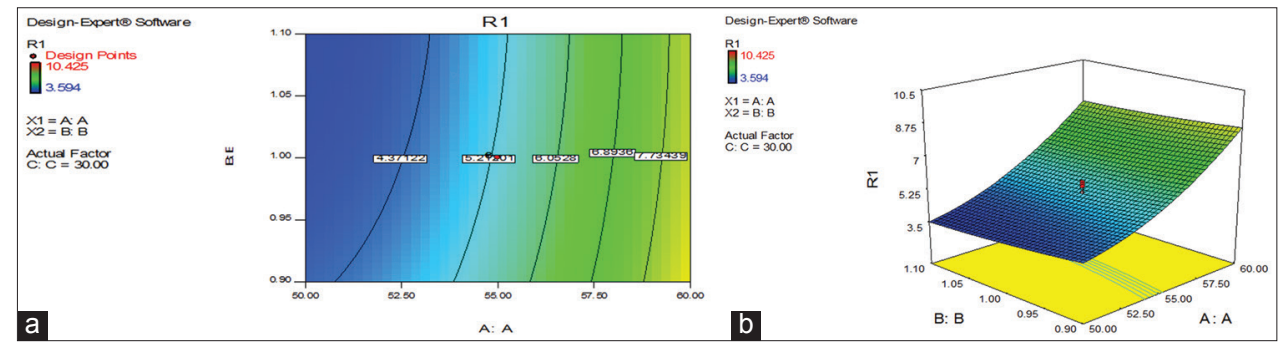

Fig. 3: Response surface (a) and contour plots (b) for retention time as a function of orthophosphoric acid \% in mobile phase and flow rate, $\mathrm{ml} / \mathrm{min}$ (contact temperature: $30^{\circ} \mathrm{C}$ )

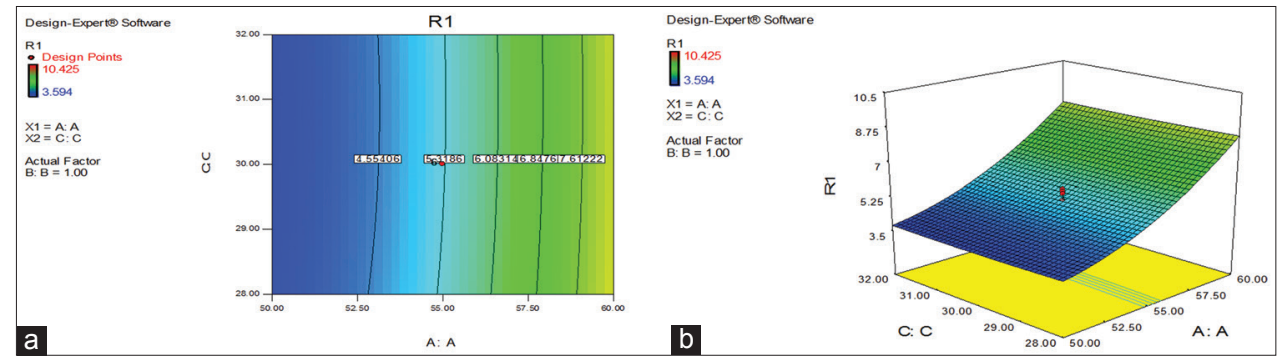

Fig. 4: Response surface (a) and contour plots (b) for retention time as a function of orthophosphoric acid \% in mobile phase and temperature, ${ }^{\circ} \mathrm{C}$ (constant flow rate, $1.00 \mathrm{ml} / \mathrm{min}$ )

Table 6: ANOVA for quadratic model for method response - resolution

\begin{tabular}{|c|c|c|c|c|c|c|}
\hline Source & $\begin{array}{l}\text { Sum of } \\
\text { squares }\end{array}$ & df & $\begin{array}{l}\text { Mean } \\
\text { square }\end{array}$ & F-value & $p$ value & \\
\hline Model & 16.54 & 9 & 1.84 & 10.51 & 0.0005 & Significant \\
\hline A-MP & 4.64 & 1 & 4.64 & 26.55 & 0.0004 & \\
\hline B-FR & 6.392E-003 & 1 & 6.392E-003 & 0.037 & 0.8522 & \\
\hline C-TMP & 0.30 & 1 & 0.30 & 1.69 & 0.2228 & \\
\hline $\mathrm{AB}$ & 8.82 & 1 & 8.82 & 50.43 & $<0.0001$ & \\
\hline $\mathrm{AC}$ & 0.13 & 1 & 0.13 & 0.71 & 0.4177 & \\
\hline$A^{2}$ & 2.54 & 1 & 2.54 & 14.52 & 0.0034 & \\
\hline $\mathrm{B}^{2}$ & 0.034 & 1 & 0.034 & 0.19 & 0.6689 & \\
\hline $\mathrm{C}^{2}$ & $2.908 \mathrm{E}-004$ & 1 & $2.908 \mathrm{E}-004$ & 1.663E-003 & 0.9683 & \\
\hline Residual & 1.75 & 10 & 0.17 & & & \\
\hline Lack of fit & 1.44 & 5 & 0.29 & 4.67 & 0.0580 & Not significant \\
\hline Pure & 0.31 & 5 & 0.062 & & & \\
\hline \multicolumn{7}{|l|}{ Error } \\
\hline Cor Total & 18.29 & 19 & 18.29 & & & \\
\hline SD & 0.42 & PRESS & 11.45 & Adequate precision & 12.716 & \\
\hline $\mathrm{R}^{2}$ & 0.9044 & $\begin{array}{l}\text { Adjusted } \\
\mathrm{R}^{2}\end{array}$ & 0.8183 & Predicted $\mathrm{R}^{2}$ & 0.3739 & \\
\hline
\end{tabular}




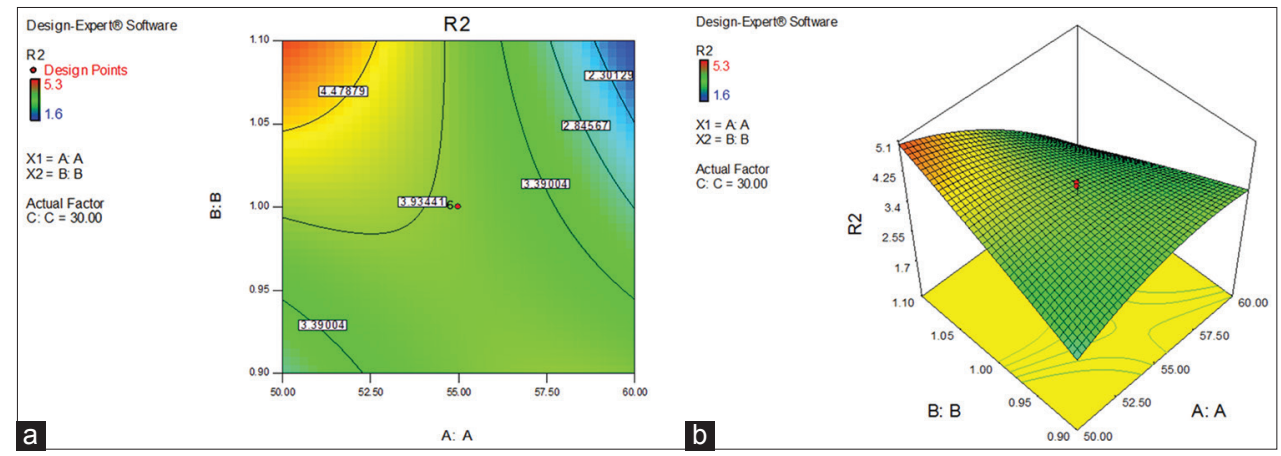

Fig. 5: Response surface (a) and contour plots (b) for the resolution as a function of orthophosphoric acid \% in mobile phase and flow rate, $\mathrm{ml} / \mathrm{min}$ (contact temperature: $30^{\circ} \mathrm{C}$ )
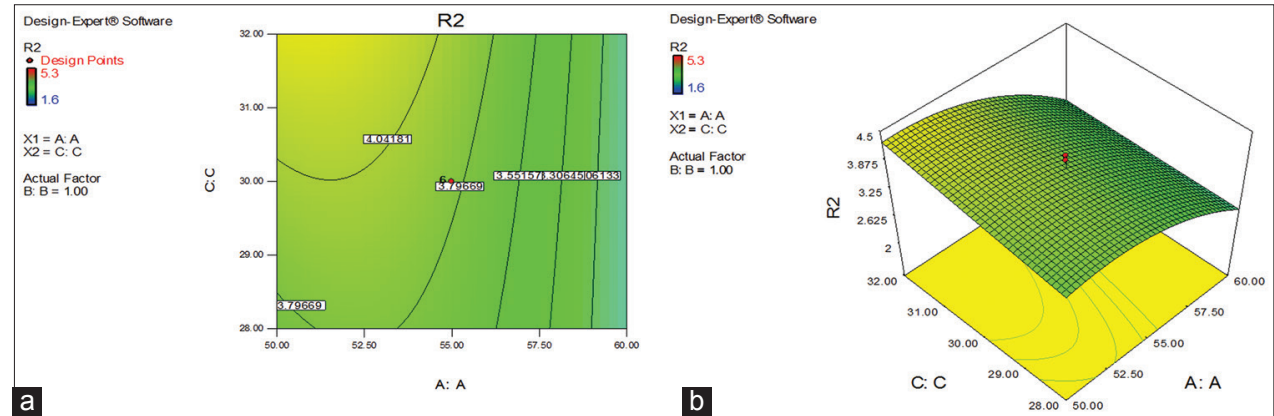

Fig. 6: Response surface (a) and contour plots (b) for resolution as a function of orthophosphoric acid \% in mobile phase and temperature, ${ }^{\circ} \mathrm{C}$ (constant flow rate of $1.00 \mathrm{ml} / \mathrm{min}$ )

shows that if method operated at high levels of \% OPA and temperature, the method response resolution achieved $<3.6$. But operating the method at low level of OPA \%(<55\%) and high level of temperature $\left(>30^{\circ} \mathrm{C}\right)$ can gives rise the resolution more than 4 .

The $\%$ OPA in mobile phase kept constant at 55 , and the interaction of flow rate and column temperature was studied which shows the least effect on resolution. Hence, it is considered as insignificant terms for this proposed model.

\section{Design space}

The design space can provide a suitable method performance such as retention time and resolution of the method within the space. The method failure has been detected by a proper understanding of method variable interaction by keeping constant of one variable and studying the two factors interaction on method performance. By careful observation of the contour and 3D diagram, the design space for the method was obtained which can produce acceptable system suitability parameters values as given in Table 7.

\section{Method optimization through DoE software}

The accuracy of the model was evaluated by numerical optimization method by the Design-Expert software. The desired goals for method response, retention time (3.594-10.425), and Resolution (1.6-5.3) were set as in rage. 30 solutions were suggested, but based on desirability 1.0, the software selected one condition. The experiment run was conducted based on the optimal condition mentioned in Design-Expert. The chromatographic conditions suggested by Design-Expert were $\%$ OPA in mobile phase at $51.3 \%$, flow rate at $0.94 \mathrm{ml} / \mathrm{min}$, and column temperature at $30.13^{\circ} \mathrm{C}$ and predicted method responses by the model were retention time at $4.27 \mathrm{~min}$ and resolution at 3.56 as shown in Fig. 7.

The same experimental conditions were maintained and run the HPLC system. The optimized chromatogram of simeprevir with peroxide impurities was obtained as indicated in Fig. 8 and it produced satisfactory system suitability parameters. The method responses of simeprevir in chromatogram had shown almost nearer to predict values.

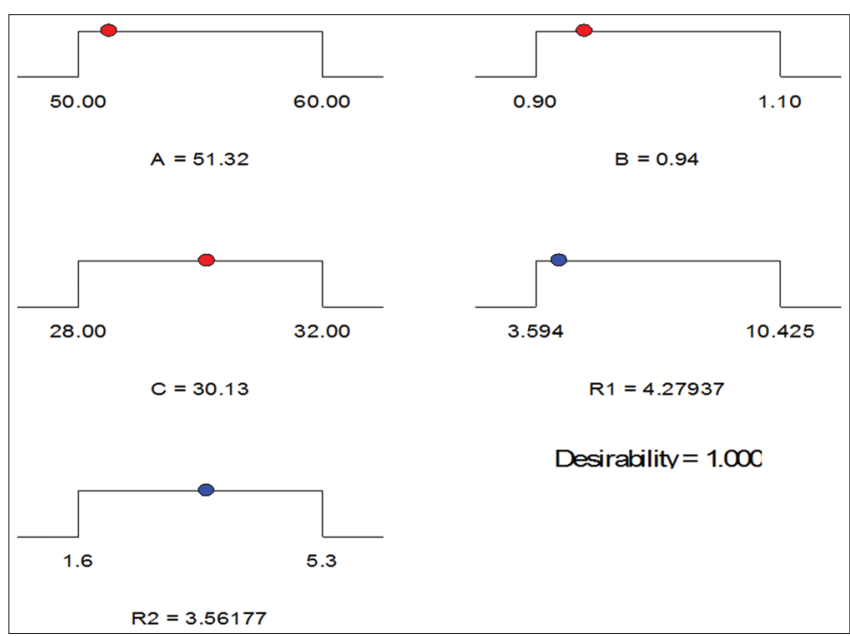

Fig. 7: Optimization and prediction of method responses by model

The verification data of predicted values by the model and observed values are given in Table 8

The correlation between the predicted values and observed values was found to be 1 as given in Fig. 9. Hence,the model successfully can predict the method response within the $95 \%$ of the confidence interval of low and high.

The proposed optimized method was validated as per ICH parameters. Validation summary data are provided in Table 9.

\section{DISCUSSION}

A novel, selective, robust stability-indicating RP-HPLC method was developed for the estimation of simeprevir in bulk drug by $\mathrm{QbD}$ approach. Initial method was developed using OPA and ACN 


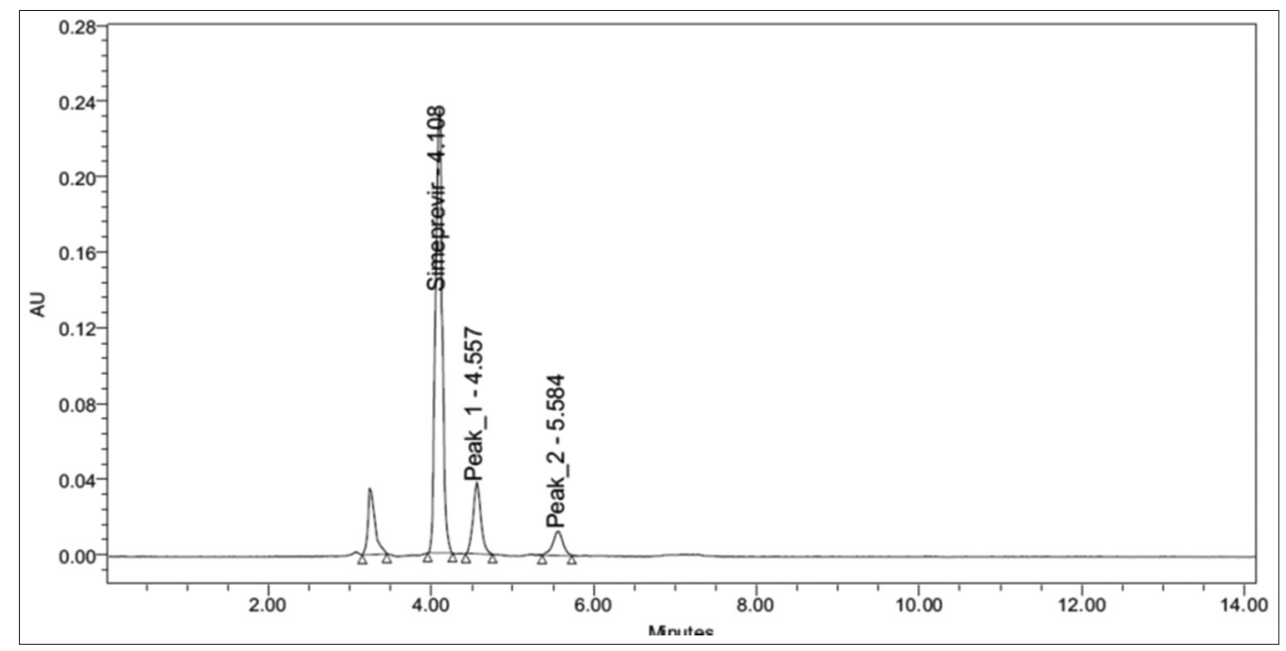

Fig. 8: Optimization chromatogram of simeprevir in peroxide degradation

Table 7: Method operable design region

\begin{tabular}{|c|c|c|c|}
\hline \multirow{2}{*}{$\begin{array}{l}\text { Constant factor } \\
\text { Y1 }\end{array}$} & \multicolumn{3}{|c|}{ Variable range for method response } \\
\hline & $\begin{array}{l}\text { Factor A } \\
(\% \text { OPA) }\end{array}$ & $\begin{array}{l}\text { Factor B } \\
\text { (Flow rate } \\
\text { ml/min) }\end{array}$ & $\begin{array}{l}\text { Factor C } \\
\text { (Temperature } \\
\left.{ }^{\circ} \mathrm{C}\right)\end{array}$ \\
\hline Temperature $\left(30^{\circ} \mathrm{C}\right)$ & $50-55$ & $0.9-1.0$ & Constant \\
\hline Flow rate $(1.0 \mathrm{ml} / \mathrm{min})$ & $50-55$ & Constant & $28-32$ \\
\hline $\begin{array}{l}\% \text { OPA in mobile } \\
\text { phase }(55 \%)\end{array}$ & Constant & $0.9-1.0$ & $28-32$ \\
\hline
\end{tabular}

OPA: Orthophosphoric acid

Table 8: Verification of experiment at optimum conditions

\begin{tabular}{lllll}
\hline $\begin{array}{l}\text { Method } \\
\text { response }\end{array}$ & Prediction & $\begin{array}{l}\mathbf{9 5 \%} \text { CI } \\
\text { low }\end{array}$ & $\begin{array}{l}\mathbf{9 5 \%} \text { CI } \\
\text { high }\end{array}$ & Observed \\
\hline $\begin{array}{l}\text { Retention time } \\
\text { Resolution }\end{array}$ & 4.27 & 3.81 & 4.75 & 4.108 \\
\hline
\end{tabular}

CI: Confidence interval

Table 9: Validation summary of simeprevir

\begin{tabular}{ll}
\hline Parameters & Simeprevir \\
\hline Linearity & \\
Range & $25-150 \mu \mathrm{g} / \mathrm{ml}$ \\
Slope & 41,204 \\
Intercept & 66,756 \\
LOD $(\mu \mathrm{g} / \mathrm{mL})$ & $0.96 \mu \mathrm{g} / \mathrm{ml}$ \\
LOQ $(\mu \mathrm{g} / \mathrm{mL})$ & $2.90 \mu \mathrm{g} / \mathrm{ml}$ \\
Accuracy (Average recovery \%) & 101.89 \\
Precision (\% RSD) & \\
Intraday precision & 0.2 \\
$\quad$ Inter day precision & 0.3 \\
Robustness & Robust \\
\hline
\end{tabular}

LOD: Limits of detection, LOQ: Limits of quantification, RSD: Relative standard deviation

(55:45\% v/v) with the flow rate of $1 \mathrm{ml} / \mathrm{min}$ at $300 \mathrm{~nm}$. The drug was subjected to various stress conditions such as hydrolysis (acid, alkali, and neutral), peroxide, and thermal. Under peroxide stress conditions, the chromatogram shows more number of critical impurity peaks which affect the selectivity of method. To resolve it, the design of experiment was applied. In response surface method, central composite design was used by taking three factors like $\% \mathrm{OPA}, \mathrm{pH}$, and flow rate as input variables. The retention time and resolution were output variables.

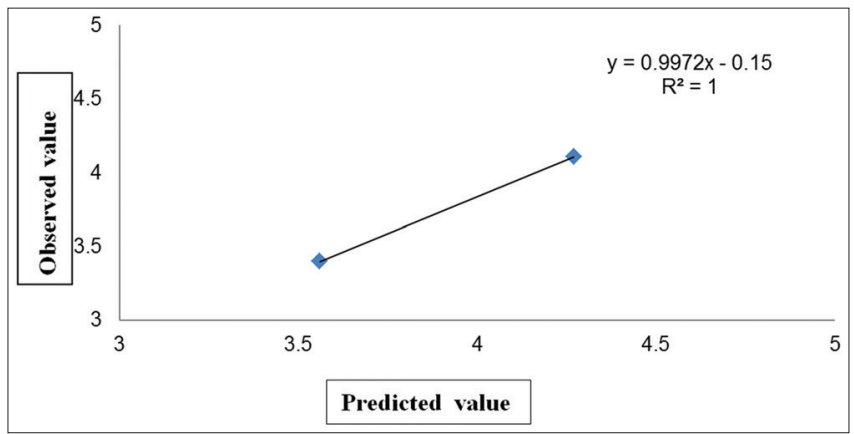

Fig. 9: Correlation graph of predicted values versus observed values

The statistical tools were implemented to know the significant effect of each factor on method responses. The polynomial equation was derived for retention time and resolution. Chromatographic conditions suggested by Design-Expert were OPA \% in mobile phase at $51.3 \%$, flow rate at $0.94 \mathrm{ml} / \mathrm{min}$, and column temperature at $30.13{ }^{\circ} \mathrm{C}$. The model predicted that the retention time of simeprevir was 4.27 and resolution was 3.56. The method was verified by performing the above-mentioned chromatographic conditions. The retention time and resolution obtained in these conditions were $4.108 \mathrm{~min}$ and 3.4. With $95 \%$ of confidence interval, the proposed model can predict the response variables. The optimized method was validated as per the ICH Q2 (R1) guidelines.

\section{CONCLUSION}

A quadratic model of a central composite design with a high degree of correlation and predicting ability was developed to predict the retention time of simeprevir and resolution between simeprevir and its degradant using OPA \% in mobile phase, flow rate, and column temperature as method variables. Interaction among all the variables was investigated by employing RSM. The significant effect was shown by $\%$ OPA in mobile phase on both response retention time and resolution. The accuracy of the model was tested by running the chromatographic condition suggested by the model. The forecast values of retention time and resolution by the design were matched with the observed values. The method was optimized and validated as per the ICH guidelines.

\section{ACKNOWLEDGMENT}

The Principal author (VANITHA C) thanks Sri Venkateswara College of Pharmacy, RVS Nagar, Chittoor, Andhra Pradesh, for providing research facilities for successful completion of this research work. 


\section{AUTHORS' CONTRIBUTIONS}

The article was taken from the research work of Vanitha $C$ under the guidance of supervisor Dr. K. Bhaskar Reddy and co-supervisor Prof. S.V. Satyanarayana as a part of her PhD work. All authors have made considerable contributions to the work reported in the manuscript.

\section{CONFLICTS OF INTEREST}

The authors declare that they have no conflicts of interest.

\section{REFERENCES}

1. Bakshi M, Singh S. Development of validated stability-indicating assay methods-critical review. J Pharm Biomed Anal 2002;28:1011-40.

2. ICH Q8 Quality Guidance: Pharmaceutical Development; 2009.

3. A Report of World Health Organization's on Hepatitis C virus. Available from: https://www.who.int/news-room/fact-sheets/detail/hepatitis-c. [Last accessed on 2019 Mar 17]

4. Izquierdo L, Helle F, François C, Castelain S, Duverlie G, Brochot E. Review on Simeprevir for the treatment of Hepatitis $C$ virus infection. Pharmgenomics Pers Med 2014;7:241-9.

5. Kanda T, Nakamoto S, Wu S, Yokosuka O. Review on new treatments for genotype 1 chronic hepatitis $\mathrm{C}$ focus on simeprevir. Ther Clin Risk Manag 2014;10:387-7.

6. Attia KA, El-Abasawi NM, El-Olemy A, Serag A. Stability-indicating HPLC-DAD method for the determination of simeprevir. Anal Chem Lett 2017;7:43-8.
7. Vanwelkenhuysen I, De Vries R, Timmerman P, Janssen TV. Determination of simeprevir: A novel, hepatitis $\mathrm{C}$ protease inhibitor inhuman plasma by high-performance liquid chromatography tandem mass spectrometry. J Chromatogr B 2014;958:43-4.

8. Ariaudo A, Favata F, De Nicolò A, Simiele M, Paglietti L, Boglione L, et al. A UHPLC-MS/MS method for the quantification of direct antiviral agents simeprevir, daclatasvir, ledipasvir, sofosbuvir/GS331007, dasabuvir, ombitasvir and paritaprevir, together with ritonavir, inhuman plasma. J Pharm Biomed Anal 2016;125:369-6.

9. Nannetti G, Pagni S, Parisi SG, Alberti A, Loregian A, Palù G. Development of a simple HPLC-UV method for the determination of the Hepatitis $C$ virus inhibitor simeprevir in human plasma. J Pharm Biomed Anal 2016;121:197-6.

10. Attia KA, El-Abasawi NM, El-Olemy A, Serag A. Different spectrophotometric methods applied for the analysis of simeprevir in the presence of its oxidative degradation product: A comparative study. Spectrochim Acta A Mol Biomol Spectrosc 2018;190:1-9.

11. Attia KA, El-Abasawi NM, El-Olemy A, Serag A. Simeprevir oxidative degradation product: Molecular modeling, in silico toxicity and resolution by synchronous spectro flourimetry. Luminescence 2017;33:1-9.

12. Zope MV, Patel RM, Patel AK, Patel SG. Development and validation of a stability indicating RP-HPLC method for the determination of potential degradation products of difluprednate in ophthalmic emulsion. Int J Pharm Pharm Sci 2018;10:79-7.

13. Prasad SN, Patel HK, Gothoskar AV. QBD-based development and evaluation of enteric coated mucoadhesive microcapsules of amoxicillin trihydrate as a novel chronotherapeutic approach for treatment of bacterial infections. Int J Pharm Pharm Sci 2018;10:90-100. 